\title{
4 Debris-Flow Hazards in the United States
}

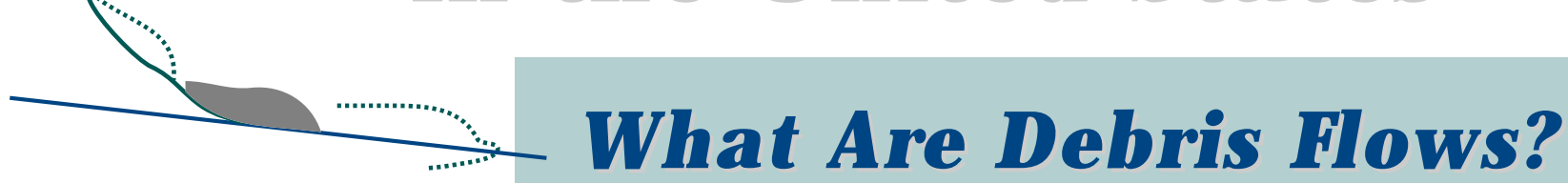

ome landslides move slowly and cause damage gradually, whereas others move so rapidly that they can destroy property and take lives suddenly and unexpectedly. Debris flows, sometimes referred to as mudslides, mudflows, lahars, or debris avalanches, are common types of fast-moving landslides. These flows generally occur during periods of intense rainfall or rapid snowmelt. They usually start on steep hillsides as shallow landslides that liquefy and accelerate to speeds that are typically about $10 \mathrm{mph}$, but can exceed $35 \mathrm{mph}$. The consistency of debris flows ranges from watery mud to thick, rocky mud that can carry large items such as boulders, trees, and cars. Debris flows from many different sources can combine in channels where their destructive power may be greatly increased. They continue flowing down hills and through channels, growing in volume with the addition of water, sand, mud, boulders, trees, and other materials. When the flows reach canyon mouths or flatter ground, the debris spreads over a broad area, sometimes accumulating in thick deposits that can wreak havoc in developed areas.
D ebris flows are fast-moving landslides that occur in a wide variety of environments throughout the world. They are particularly dangerous to life and property because they move quickly, destroy objects in their paths, and often strike without warning. U.S. Geological Survey (USGS) scientists are assessing debris-flow hazards in the United States and elsewhere, and developing real-time techniques for monitoring hazardous areas so that road closures, evacuations, or corrective actions can be taken.

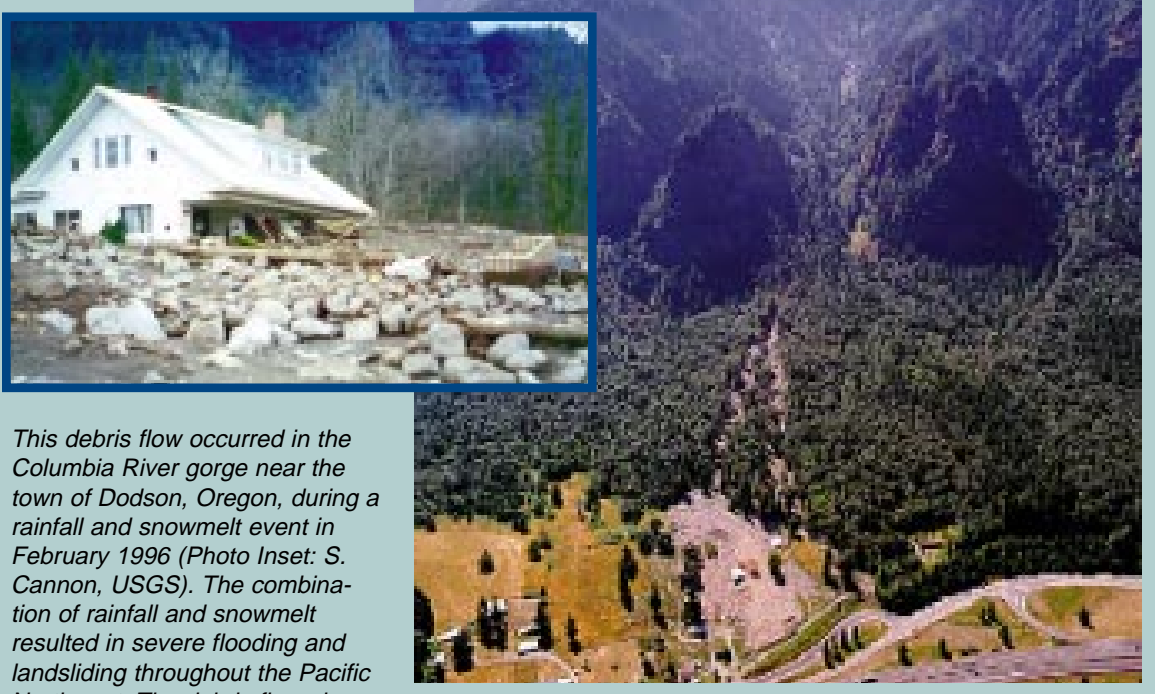

landsliding throughout the Pacific

Northwest. The debris flow shown

here was deposited in a number of separate events over a period of 2 days. The flows originated high on the palisade and traveled through the steep canyon. The occupants of the house escaped with their lives when they heard a loud rumbling and crashing of trees and saw the approaching material through their kitchen window. Boulders, mud, and debris from these and several nearby debris flows were deposited across the east-bound lanes of Interstate Highway 84, and blocked the highway for 5 days (Aerial Photo: D. Wieprecht, USGS).

\section{Dangerous, Fast-Moving Landslides}

Fast-moving flows of mud and rock, called debris flows or mudslides, are among the most numerous and dangerous types of landslides in the world. They are particularly dangerous to life and property because of their high speeds and the sheer destructive force of their flow. These flows are capable of destroying homes, washing out roads and bridges, sweeping away vehicles, knocking down trees, and obstructing streams and roadways with thick deposits of mud and rocks. Debris flows are typically associated with periods of heavy rainfall or rapid snowmelt and tend to worsen the effects of flooding that often accompanies these events. Finally, in areas burned by forest and brush fires, a lower threshold of precipitation may initiate debris flows. 


\section{Where do debris flows occur?}

\section{Debris Flows in the Western United States}

Highly destructive debris flows occur in many areas across the United States. Hilly areas subject to prolonged, intense rainfall are particularly susceptible. Areas throughout southern California are frequently beset by debris-flow problems, and public agencies have expended vast resources on massive debris-protection systems for more than 65 years. The San Francisco Bay region also has experi- enced damaging debris-flow episodes throughout this century. El Niño, the ocean-warming phenomenon that can produce heavier-than-usual rainfall in certain areas of the United States, was associated with countless debris flows in Utah, when El Niño's increased rainfall effects were felt during the early 1980's. Hilly areas of Hawaii experience much destruction from debris flows, as do areas of extreme northern California, Idaho, Oregon, and Washington. The mountains of Colorado and the Sierra Nevada of California have also experienced debris flows in areas receiving high rates of rainfall, rapid snowmelt, or a combination of these. As more people populate hilly areas of the west, the potential for damage from debris flows increases.

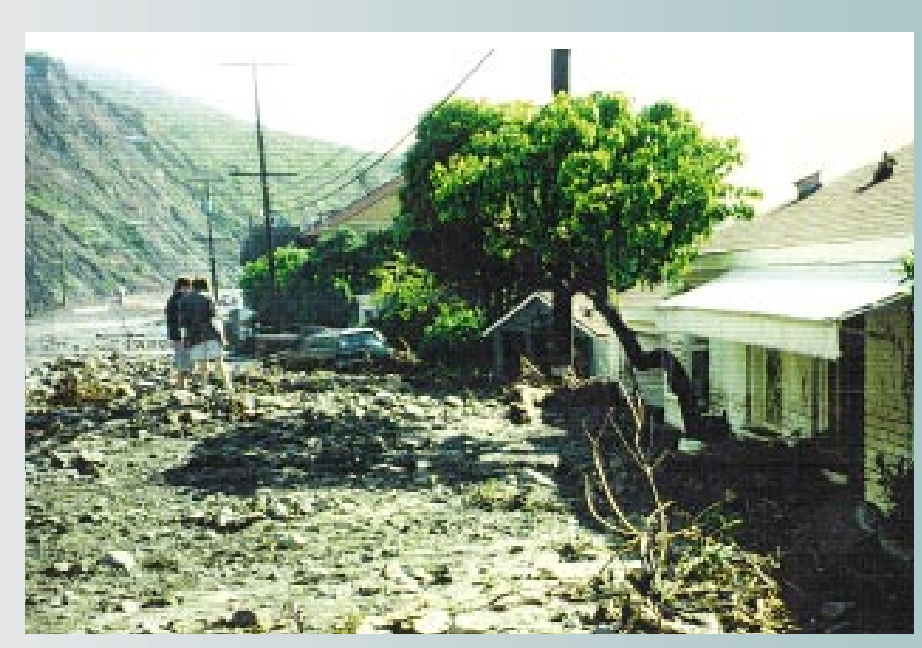

During late May and early June of 1983, a series of debris flows emerged from Rudd Canyon into the community of Farmington, Utah. Although no one was injured, a number of houses were inundated and destroyed by debris flows. Due in part to USGS studies, debris basins were constructed here and elsewhere along the Wasatch Front north of Salt Lake City to prevent subsequent damage. Utah was particularly hard hit by landslides and debris flows during the EI Niño events that struck the United States in the early 1980's (Photo: S. Ellen, USGS).

Damage from a March 1995 debris flow that issued from Peña Canyon, Malibu, California. View is looking east along California State Highway 1 (Pacific Coast Highway) (Photo: California Department of Transportation).

\section{Debris Flows in the Eastern United States}

Debris flows are not limited to areas of the Western United States. Many debrisflow disasters have also occurred in hilly and mountainous regions of the Central and Eastern United States, particularly in the Appalachian Mountains. Thousands of debris flows in several eastern States were caused by heavy rainfall from hurricane Camille as it moved inland from the Atlantic Ocean in 1969. During an intense storm on June 27, 1995 in Madison County, Virginia, 30 inches of rain fell in 16 hours. Hundreds of debris flows occurred in the mountainous areas of the county amid widespread flooding. Many houses and barns were inundated or crushed by debris; pastures and cornfields were buried; and livestock perished. One flow near Graves Mill, Virginia, traveled nearly 2 miles, and an eyewitness estimated that it moved at a speed approaching 20 miles per hour. The combined flood and debris-flow devastation prompted a Federal disaster declaration for the county. 


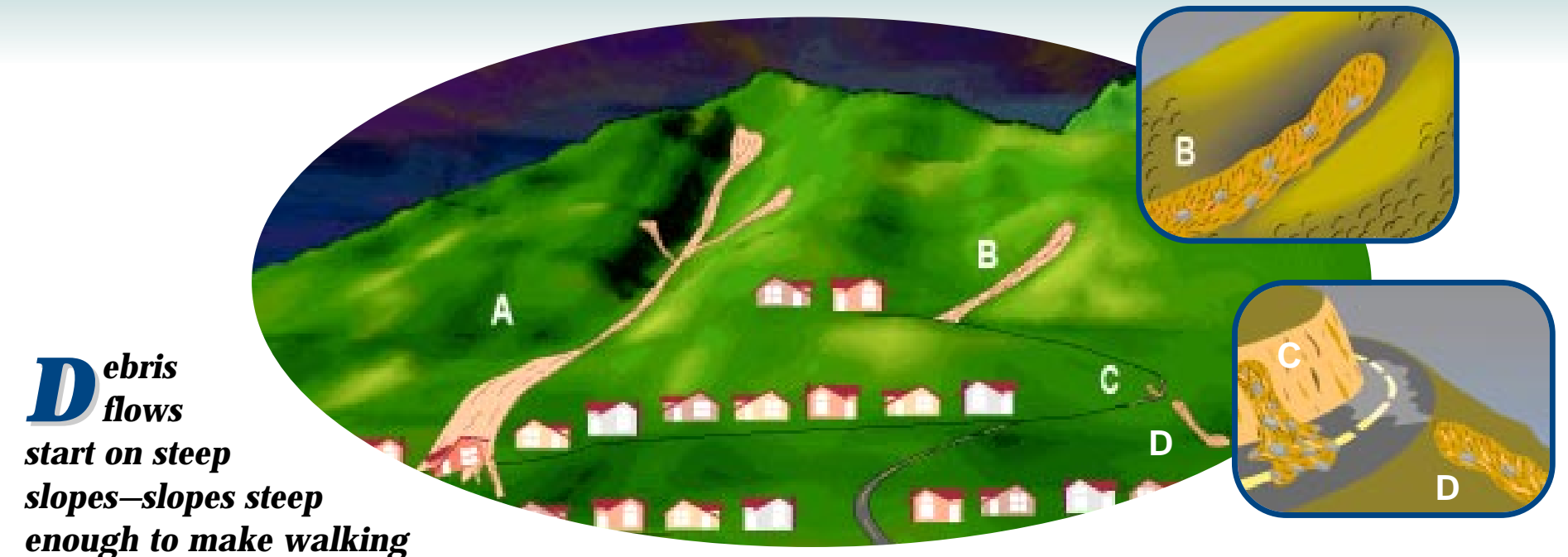

enough to make walking

difficult. Once started, howev-

er, debris flows can travel even

over gently sloping ground.

The most hazardous areas are canyon bottoms, stream channels, areas near the outlets of canyons, and slopes excavated for buildings and roads.

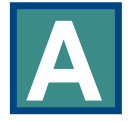

Canyon bottoms, stream channels, and areas near the outlets of canyons or channels are particularly hazardous. Multiple debris flows that start high in canyons commonly funnel into channels. There, they merge, gain volume, and travel long distances from their sources.

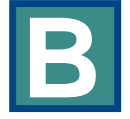

Debris flows commonly begin in swales (depressions) on steep slopes, making areas downslope from swales particularly hazardous.

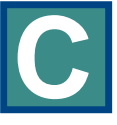

Roadcuts and other altered or excavated areas of slopes are particularly susceptible to debris flows. Debris flows and other landslides onto roadways are common during rainstorms, and often occur during milder rainfall conditions than those needed for debris flows on natural slopes.

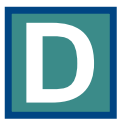
Areas where surface runoff is channeled, such as along roadways and below culverts, are common sites of debris flows and other landslides.

\section{Wildfires and Debris Flows}

Wildfires can also lead to destructive debris-flow activity. In July 1994, a severe wildfire swept Storm King Mountain west of Glenwood Springs, Colorado, denuding the slopes of vegetation. Heavy rains on the mountain in September resulted in numerous debris flows, one of which blocked Interstate 70 and threatened to dam the Colorado River. A 3-mile length of the highway was inundated with tons of rock, mud, and burned trees. The closure of Interstate 70 imposed costly delays on this major transcontinental highway. Here, as in other areas, the USGS assisted in analyzing the debris-flow threat and installing monitoring and warning systems to alert local safety officials when high-intensity rainfall occurred or debris flows passed through a susceptible canyon. Similar types of debris flows threaten transportation corridors and other development throughout the West in and near fire-ravaged hillsides.

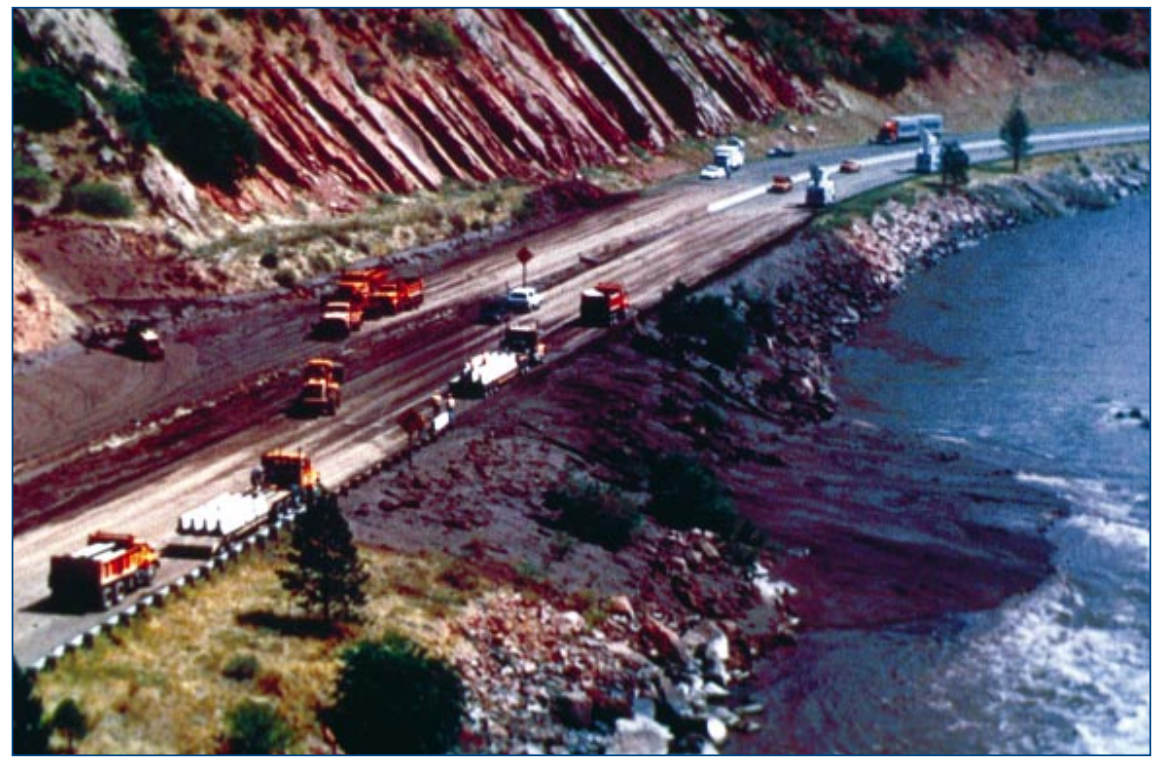

Debris flows like these near Glenwood Springs, Colorado, are a consequence of heavy rainfall on burned hillsides. In addition to personal injuries and damage to 30 vehicles engulfed by these flows, transportation along the Interstate 70 corridor was brought to a standstill for a day, and business and emergency operations in the Glenwood Springs area were seriously impeded (Photo: Jim Scheidt, U.S. Bureau of Land Management). 


\section{Debris Flows and Volcanoes}

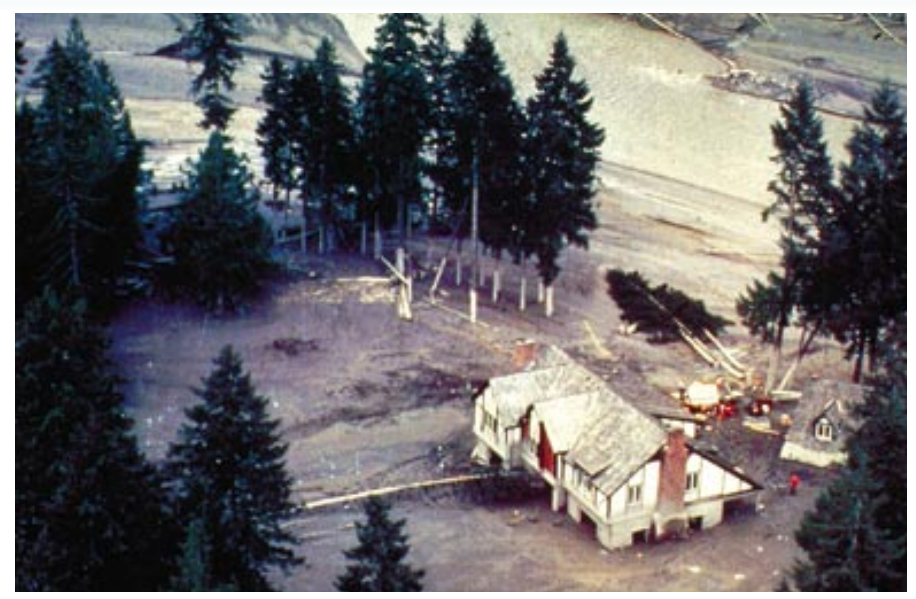

During the 1980 eruption of Mount St. Helens, a debris flow traveled about 14 miles down the valley of the North Fork Toutle River. It destroyed nine highway bridges, many miles of highways and roads, and about 200 homes on the flood plain of the Toutle River (Photo: D. Crandell, USGS).
Among the most destructive types of debris flows are those that accompany volcanic eruptions. A spectacular example in the United States was a massive debris flow resulting from the 1980 eruptions of Mount St. Helens, Washington. Areas near the bases of many volcanoes in the Cascade Mountain Range of California, Oregon, and Washington are at risk from the same types of flows during future volcanic eruptions. In areas with vulnerable populations, such as the valleys near Mt. Rainier in Washington, scientists are producing hazard maps that delineate debris-flow dangers. In many cases, the USGS works with other agencies installing hazard-detection and warning systems, and developing means for communicating hazards and warnings about volcanic eruptions and debris flows.

\section{What can you do if you live near steep hills?}

\section{Prior to Intense Storms:}

1 Become familiar with the land around you. Learn 1 whether debris flows have occurred in your area by contacting local officials, State geological surveys or departments of natural resources, and university departments of geology. Slopes where debris flows have occurred in the past are likely to experience them in the future.

2 Support your local government in efforts to develop 2 and enforce land-use and building ordinances that regulate construction in areas susceptible to landslides and debris flows. Buildings should be located away from steep slopes, streams and rivers, intermittent-stream channels, and the mouths of mountain channels.

\section{Watch the patterns of storm-water drainage on slopes 3 near your home, and note especially the places where runoff water converges, increasing flow over soil-covered slopes. Watch the hillsides around your home for any signs of land movement, such as small landslides or debris flows or progressively tilting trees.}

Contact your local authorities to learn about the emergency-response and evacuation plans for your area and develop your own emergency plans for your family and business.

\section{During Intense Storms:}

1 Stay alert and stay awake! Many debris-flow fatalities 1 occur when people are sleeping. Listen to a radio for warnings of intense rainfall. Be aware that intense short bursts of rain may be particularly dangerous, especially after longer periods of heavy rainfall and damp weather.

If you are in areas susceptible to landslides and debris 2 flows, consider leaving if it is safe to do so. Remember that driving during an intense storm can itself be hazardous.

3

Listen for any unusual sounds that might indicate mov3 ing debris, such as trees cracking or boulders knocking together. A trickle of flowing or falling mud or debris may precede larger flows. If you are near a stream or channel, be alert for any sudden increase or decrease in water flow and for a change from clear to muddy water. Such changes may indicate landslide activity upstream, so be prepared to move quickly. Don't delay! Save yourself, not your belong ings.

Be especially alert when driving. Embankments along roadsides are particularly susceptible to landslides. Watch the road for collapsed pavement, mud, fallen rocks, and other indications of possible debris flows.

Lynn M. Highland, Stephenson D. Ellen, Sarah B. Christian, and William M. Brown III

\section{COOPERATING AGENCIES}

The USGS cooperates with many Federal, State, local, and international agencies on debris-flow hazards assessments, warning systems, and disaster analyses. Principal cooperators for events discussed in this Fact Sheet include:

California Division of Mines and Geology California Department of Transportation Colorado Department of Transportation Colorado Geological Survey

Federal Emergency Management Agency Garfield County, Colorado
Madison County, Virginia

San Mateo County, California

U.S. Army Corps of Engineers

U.S. Bureau of Land Management

U.S. Forest Service

U.S. National Weather Service o help prepare for debris flows and lessen their impacts, scientists from the USGS Landslide Hazards Program conduct research on debris-flow processes. An example of this research is the assessment of rainfall thresholds for debris-flow initiation. These thresholds are used for local and regional debris-flow warning systems. Additional Landslide Program activities indude evaluation of debrisflow susceptibility at national and regional scales and emergency response to debris-flow emergencies and disasters, both in the United States and in cooperation with foreign countries.
For more information, contact:

U.S. Geological Survey

National Landslide Information Center Federal Center, Box 25046, MS 966

Denver, CO 80225-0046 USA

Tel: 1-800-654-4966

email: NLIC@usgs.gov

http://geohazards.cr.usgs.gov

Graphic design by Pamela S. Detra 